\begin{tabular}{|c|c|c|}
\hline B! & $\begin{array}{l}\text { BIODIK: Jurnal IImiah Pendidikan Biologi } \\
\text { ISSN 2580-0922 (online), ISSN 2460-2612 (print) } \\
\text { Volume 07, Nomor 04, Tahun 2021, Hal. 70-76 } \\
\text { Available online at: } \\
\text { https://online-journal.unja.ac.id/biodik }\end{array}$ & BIODIK \\
\hline
\end{tabular}

Research Article

open 2 ACCESS

\title{
Analisis Minat dan Hasil Belajar Biologi Siswa pada Pembelajaran Daring di SMA Negeri Purwodadi Kabupaten Musi Rawas
}

\section{(Analysis of Student Biology Interests and Learning Outcomes in Online Learning at Purwodadi Public High School, Musi Rawas Regency)}

Septi Kurnia*, Saleh Hidayat, Sri Wardhani

Program Pascasarjana Pendidikan Biologi, Universitas Muhammadiyah Palembang Jalan Jend. Ahmad Yani 13 Ulu Palembang-Sumatera Selatan-Indonesia

*corresponding author: septikurnia100@gmail.com

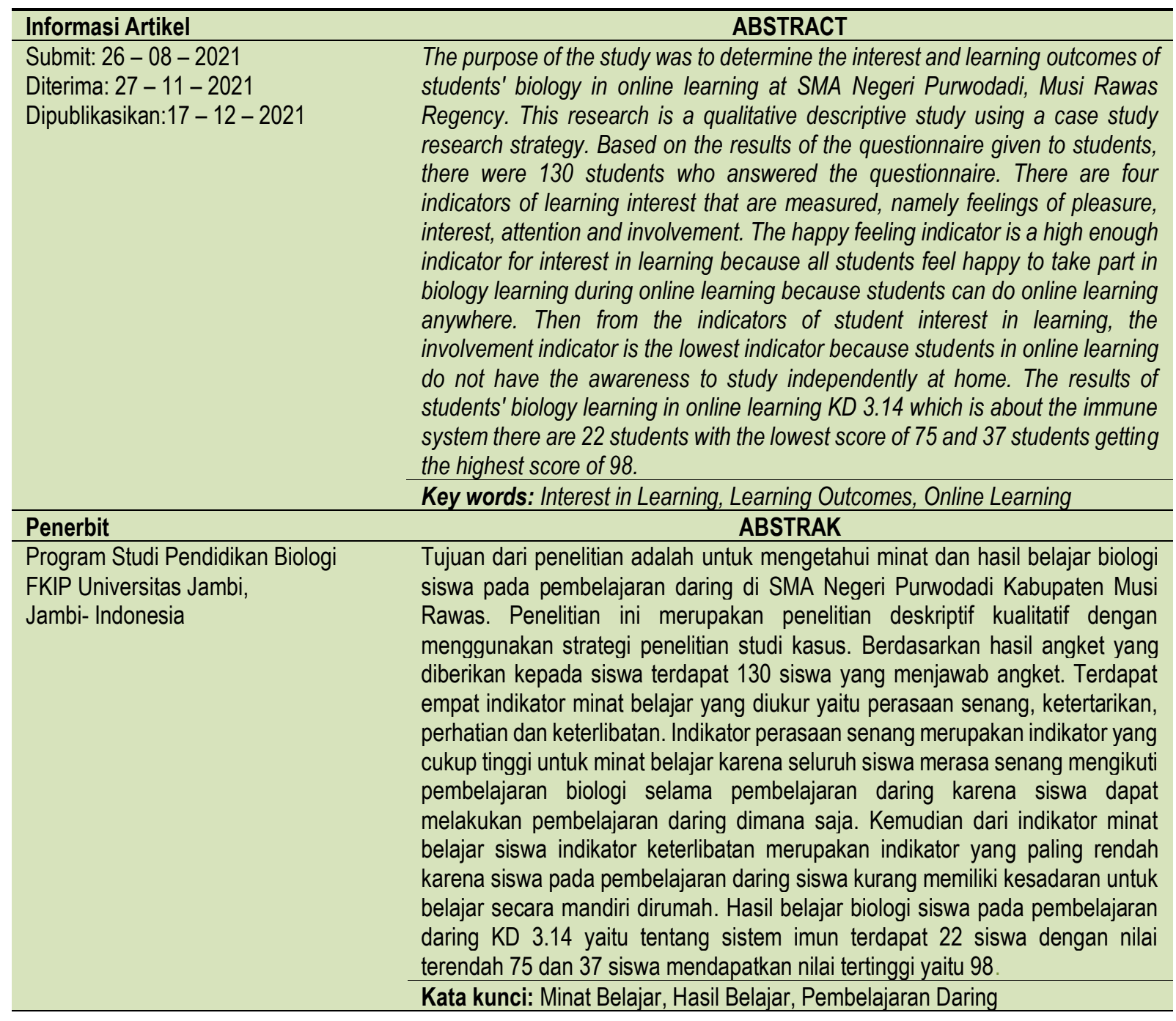


This BIODIK : Jurnal IImiah Pendidikan Biologi is licensed under a CC BY-NC-SA (Creative Commons Attribution-ShareAlike 4.0 International License)

\section{PENDAHULUAN}

Pendidikan merupakan suatu proses yang diperlukan untuk mendapatkan keseimbangan dan kesempurnaan dalam perkembangan individu maupun masyarakat. Penekanan pendidikan dibanding dengan pengajaran terletak pada pembentukan kesadaran dan kepribadian individu atau masyarakat di samping transfer ilmu dan keahlian. Proses semacam ini suatu bangsa atau negara dapat mewariskan nilai-nilai keagamaan, kebudayaan, pemikiran, dan keahlian kepada generasi berikutnya, sehingga mereka betul-betul siap menyongsong masa depan kehidupan bangsa dan negara yang lebih cerah (Nurkholis, 2013:25).

Sejak awal tahun 2020, dunia dikejutkan dengan wabah virus corona (COVID-19) yang menginfeksi hampir seluruh negara di dunia. WHO semenjak Januari 2020 telah menyatakan dunia masuk ke dalam darurat global terkait virus ini. Virus corona yang menyerang sistem pernapasan ini telah mencatat lebih dari 28 juta kasus dari 213 negara didunai yang terinfeksi. Wabah global telah melanda dunia, begitu pula yg terjadi di Indonesia, sehingga program stay at home dilaksanakan sebagai upaya menekan perluasan Covid-19. Untuk menaati program pemerintah, modus pembelajaran dialihkan menjadi kelas virtual, agar mahasiswa tetap mendapatkan haknya memperoleh ilmu tetapi tetap aman dengan di rumah saja. Kondisi pandemi saat ini menuntut pendidik dalam hal ini adalah guru untuk berinovasi mengubah pola pembelajaran tatap muka menjadi pola pembelajaran tanpa tatap muka atau menerapkan pembelajaran daring (Anugrahana, 2020:283).

Dewi (2020:56), menyatakan pembelajaran daring merupakan pemanfaatan jaringan internet dalam proses pembelajaran. Dengan pembelajaran daring siswa memiliki keleluasaan waktu belajar, dapat belajar kapanpun dan dimanapun. Pembelajaran daring adalah bentuk pembelajaran yang mampu menjadikan siswa mandiri tidak bergantung pada orang lain. Hal ini dikarenakan melalui pembelajaran daring siswa akan fokus pada layar gawai untuk menyelesaikan tugas ataupun mengikuti diskusi yang sedang berlangsung (Syarifudin, 2020:33). Menurut Nurhabibah dkk (2020: 258), kelemahan dalam pembelajaran daring di antaranya adalah guru sulit mengontrol keseriusan belajar siswa karena interaksi di antara keduanya menjadi terbatas dan pembelajaran membutuhkan peralatan tambahan lebih seperti kebutuhan peralatan dan teknis seperti komputer, gawai, paket data internet menjadi kendala bagi yang tinggal di pelosok dan baru menerapkan sistem pembelajaran daring.

Minat belajar adalah aspek psikologi seseorang yang menampakkan diri dalam beberapa gejala, seperti gairah, keinginan, perasaan suka untuk melakukan proses perubahan tingkah laku melalui berbagai kegiatan yang meliputi mencari pengetahuan dan pengalaman, dengan kata lain, minat belajar itu adalah perhatian, rasa suka, ketertarikan seseorang (siswa) terhadap belajar yang ditunjukkan melalui keantusiasan, partisipasi dan keaktifan dalam belajar (Sirait, 2016:38).

Hasil belajar merupakan tujuan akhir dilaksanakannya kegiatan pembelajaran di sekolah. Hasil belajar dapat ditingkatkan melalui usaha sadar yang dilakukan secara sistematis mengarah kepada perubahan yang positif yang kemudian disebut dengan proses belajar. Akhir dari proses belajar adalah perolehan suatu hasil belajar siswa. Hasil belajar siswa di kelas terkumpul dalam himpunan hasil belajar kelas. Semua hasil belajar tersebut merupakan hasil dari suatu interaksi tindak belajar dan tindak mengajar (Nasution dkk, 2017:29). 
Tujuan dari penelitian ini adalah sebagai berikut: 1) Mengetahui minat belajar biologi siswa pada pembelajaran daring di SMA Negeri Purwodadi Kabupaten Musi Rawas. 2) Mengetahui hasil belajar biologi siswa pada pembelajaran daring di SMA Negeri Purwodadi Kabupaten Musi Rawas.

\section{METODE PENELITIAN}

Penelitian ini merupakan penelitian deskriptif kualitatif dengan menggunakan strategi penelitian studi kasus. Dengan menggunakan strategi ini peneliti dapat mengetahui bagaimana minat dan hasil belajar biologi siswa pada pembelajaran daring di SMA Negeri Purwodadi Kabupaten Musi Rawas. Penelitian ini dilakukan di SMA Negeri Purwodadi, pada bulan Mei tahun 2021. Subjek dari penelitian ini adalah berjumlah 136 responden yang tediri dari 134 siswa kelas XI dan dua guru biologi. Instrumen dalam penelitian yaitu observasi, wawancara, angket (kuesioner), dokumentasi, dan data hasil belajar diperoleh dari hasil nilai ulangan harian KD 3.14 yaitu tentang materi sistem imun. Teknik analisis data yang digunakan adalah teknik analisis Miles dan Huberman. Miles dan Huberman mengemukakan bahwa aktivitas dalam analisis data diskriptif melalui tiga cara yaitu: (1) reduksi data (data reduction), (2) penyajian data (data display) dan (3) penarikan kesimpulan atau verifikasi (conclusion drawing atau verification).

\section{HASIL PENELITIAN DAN PEMBAHASAN}

\section{Minat Belajar Siswa}

Berdasarkan hasil angket (kuesioner) yang diberikan kepada siswa terdapat 130 siswa yang menjawab angket (kuesioner). Terdapat empat indikator minat belajar yang diukur yaitu perasaan senang, ketertarikan, perhatian dan keterlibatan. Hasil angket minat belajar siswa pada indikator perasaan senang dapat dilihat pada tabel 1 .

Tabel 1 Hasil angket minat belajar siswa pada indikator perasaan senang

\begin{tabular}{|c|c|c|c|c|}
\hline \multirow[t]{2}{*}{ Indikator } & \multirow[t]{2}{*}{ No } & \multirow[t]{2}{*}{ Pernyataan } & \multicolumn{2}{|c|}{ Pilihan Jawaban } \\
\hline & & & $\mathrm{Ya}$ & Tidak \\
\hline \multirow[t]{9}{*}{ Perasaan Senang } & 1 & $\begin{array}{l}\text { Saya merasa senang mengikuti pelajaran } \\
\text { biologi selama pembelajaran daring }\end{array}$ & 94 & 36 \\
\hline & 2 & $\begin{array}{l}\text { Saya tidak pernah mengeluh jika ada tugas } \\
\text { biologi dari guru }\end{array}$ & 84 & 46 \\
\hline & 3 & $\begin{array}{l}\text { Saya sering tidak hadir pada saat pelajaran } \\
\text { biologi selama pembelajaran daring }\end{array}$ & 46 & 84 \\
\hline & 4 & $\begin{array}{l}\text { Saya selalu merasa terpaksa belajar pelajaran } \\
\text { biologi }\end{array}$ & 12 & 118 \\
\hline & 5 & $\begin{array}{l}\text { Saya bersemangat belajar biologi karena guru } \\
\text { mengajar dengan menyenangkan. }\end{array}$ & 116 & 14 \\
\hline & 6 & $\begin{array}{l}\text { Guru kurang menyenangkan dalam mengajar, } \\
\text { sehingga saya menjadi malas belajar biologi }\end{array}$ & 14 & 116 \\
\hline & 7 & $\begin{array}{l}\text { Saya senang belajar biologi karena berkaitan } \\
\text { dengan kehidupan sehari-hari }\end{array}$ & 128 & 2 \\
\hline & 8 & $\begin{array}{l}\text { Saya bosan saat pelajaran biologi sedang } \\
\text { berlangsung saat pembelajaran daring }\end{array}$ & 68 & 62 \\
\hline & 22 & $\begin{array}{l}\text { Saya mengikuti pelajaran biologi tepat waktu } \\
\text { pada pembelajara daring }\end{array}$ & 69 & 61 \\
\hline
\end{tabular}

Berdasarkan tabel 1 dapat disimpulkan bahwa pada indikator perasaan senang untuk minat belajar, siswa merasa senang mengikuti pembelajaran biologi selama pembelajaran daring karena siswa dapat melakukan pembelajaran daring dimana saja. Hampir seluruh siswa merasa senang belajar biologi 
karena biologi berkaitan dengan kehidupan sehari-hari. Hal ini sesuai dengan penelitian Dalimunthe dkk, (2021: 1344), yang menyatakan bahwa para siswa sangat menyukai materi aktifitas alam dan apa yang ada disekitaran mereka, contohnya pengetahuan tentang tanaman, tumbuh-tumbuhan, binatang, organ tubuh manusia dan lain lain dengan gambar serta penjelasan yang menarik rasa ingin tahu para siswa. Sehingga daya minat mereka tinggi dalam belajar. Hasil angket minat belajar siswa pada indikator ketertarikan dapat dilihat pada tabel 2.

Tabel 2 Hasil angket minat belajar siswa pada indikator ketertarikan

\begin{tabular}{|c|c|c|c|c|}
\hline \multirow[t]{2}{*}{ Indikator } & \multirow[t]{2}{*}{ No } & \multirow[t]{2}{*}{ Pernyataan } & \multicolumn{2}{|c|}{ Pilihan Jawaban } \\
\hline & & & $\mathrm{Ya}$ & Tidak \\
\hline \multirow[t]{5}{*}{ Ketertarikan } & 9 & $\begin{array}{l}\text { Apabila mengalami kesulitan dalam memahami } \\
\text { materi, saya bertanya. }\end{array}$ & 75 & 55 \\
\hline & 10 & $\begin{array}{l}\text { Tugas yang diberikan guru membuat saya } \\
\text { semakin tertarik dengan biologi }\end{array}$ & 97 & 33 \\
\hline & 11 & $\begin{array}{l}\text { Saya kurang tertarik dengan biologi karena } \\
\text { selalu diberi tugas atau PR. }\end{array}$ & 37 & 93 \\
\hline & 19 & $\begin{array}{l}\text { Saya akan selalu berusaha mendapatkan nilai } \\
\text { yang baik pada setiap ulangan dan tugas yang } \\
\text { diberikan }\end{array}$ & 124 & 6 \\
\hline & 21 & $\begin{array}{l}\text { Saya menunda dalam mengerjakan tugas/PR } \\
\text { yang diberikan guru. }\end{array}$ & 94 & 36 \\
\hline
\end{tabular}

Berdasarkan tabel 2 dapat disimpulkan bahwa pada indikator ketertarikan minat belajar, siswa semakin tertarik dengan pelajaran biologi ketika guru memberikan materi atau tugas karena disertai dengan gambar atau video sehingga membuat siswa semakin semangat dan lebih tertarik dengan pelajaran biologi. Sejalan dengan penelitian Viviantini dkk (2015: 69), menyatakan bahwa media pembelajaran video memiliki beberapa manfaat diantaranya adalah media pembelajaran dapat meningkatkan dan mengarahkan perhatian anak sehingga dapat menimbulkan minat belajar. Hasil angket minat belajar siswa pada indikator perhatian dapat dilihat pada tabel 3 .

Tabel 3 Hasil angket minat belajar siswa pada indikator perhatian

\begin{tabular}{lllcc}
\hline Indikator & No & \multicolumn{1}{c}{ Pernyataan } & \multicolumn{2}{c}{ Pilihan Jawaban } \\
\cline { 3 - 4 } Perhatian siswa & 12 & $\begin{array}{l}\text { Saya tetap fokus belajar meski pembelajaran } \\
\text { daring }\end{array}$ & 80 & Ya \\
\cline { 2 - 4 } & 13 & $\begin{array}{l}\text { Saya mengantuk ketika belajar biologi selama } \\
\text { pembelajaran daring }\end{array}$ & 73 & 57 \\
\cline { 2 - 4 } & 14 & $\begin{array}{l}\text { Ketika ada materi biologi yang tidak saya } \\
\text { mengerti, saya mencoba mempelajarinya. }\end{array}$ & 109 & 21 \\
\cline { 2 - 4 } 15 & $\begin{array}{l}\text { Saya merasa kesulitan dalam memahami } \\
\text { materi-materi biologi selama pembelajaran } \\
\text { daring. }\end{array}$ & 102 & 28 \\
& $\begin{array}{l}\text { Materi yang diberikan guru bermanfaat bagi } \\
\text { saya }\end{array}$ & 128 & 2 \\
\hline
\end{tabular}

Berdasarkan tabel 3 dapat disimpulkan bahwa pada indikator perhatian, siswa merasa kurang fokus dengan pelajaran biologi selama pembelajaran daring kerena ketika pembelajaran daring banyak siswa yang mengakui pada saat pembelajaran daring siswa lebih sering membuka aplikasi lain seperti game online dan media sosial sehingga perhatian siswa terganggu dan siswa merasa tidak fokus. Adanya kecenderungan bermain game online mengakitbatkan anak untuk malas belajar, dalam hal seperti ini banyak ditemukan pada berbagai daerah karena orang tua membiarkan saja tanpa adanya pantaun 
khusus. Sehingga mengakibatkan anak untuk melakukan suatu hal seenaknya saja. Hal ini sesuai dengan penelitian yang dilakukan oleh Maulidar, dkk (2019: 308) game online tentu saja memberikan dampak candu pada siswa, sehingga mereka melupakan tugas mereka yang utama yaitu belajar. Akibatnya dari segi akademik mereka akan mengalami penurunan prestasi belajar. Bermain game online memberi dampak terhadap perilaku siswa, diantaranya siswa tidak fokus terhadap pelajaran dan tugasnya sebagai peserta didik. Game online ini membuat anak-anak biasa melupakan hal-hal yang lebih penting seperti belajar, mengerjakan PR, sekolah, beribadah, dan bekerja. Hasil angket minat belajar siswa pada indikator keterlibatan dapat dilihat pada tabel 4.

Tabel 4 Hasil angket minat belajar siswa pada indikator keterlibatan

\begin{tabular}{lclcc}
\hline \multirow{2}{*}{ Indikator } & \multicolumn{2}{c}{ No } & \multicolumn{1}{c}{ Pernyataan } & \multicolumn{2}{c}{ Pilihan Jawaban } \\
\cline { 3 - 5 } Keterlibatan & 16 & $\begin{array}{l}\text { Tanpa ada yang menyuruh, saya } \\
\text { belajar biologi sendiri di rumah. }\end{array}$ & 61 & 69 \\
\cline { 2 - 5 } & 17 & $\begin{array}{l}\text { Ketika di rumah saya memilih } \\
\text { bermain daripada belajar biologi. }\end{array}$ & 67 & 63 \\
\cline { 2 - 5 } & 18 & $\begin{array}{l}\text { Saya sudah belajar biologi pada } \\
\text { malam hari sebelum pelajaran esok } \\
\text { hari. }\end{array}$ & 33 & 97 \\
\hline
\end{tabular}

Berdasarkan tabel 4 dapat disimpulkan bahwa indikator keterlibatan merupakan indikator yang paling rendah karena siswa pada pembelajaran daring siswa kurang memiliki kesadaran untuk belajar secara mandiri dirumah karena siswa banyak menghabiskan waktu dengan bermain dan kurang belajar materi sebelumnya yang akan bepelajari keesokan harinya. Siswa lebih banyak menunda untuk mengumpulkan tugas yang diberikan oleh guru setelah pembelajaran daring selesai karena siswa lebih memilih menunda mengerjakan tugas karena waktu yang diberikan oleh guru untuk mengumpulkan tugas cukup panjang. Seharusnya perlu adanya pemantauan dari orang tua, dimana waktu belajar dan waktu bermain harus diatur sedemikian rupa agar anak tetap mendapat pembelajaran serta anak juga mendapatkan hiburan. Jadi antara waktu belajar dan waktu bermain di sesuaikan, hal ini akan berdampak pada kebiasaan siswa atau anak yang nantinya dapat mengontrol waktunya tidak hanya untuk bermain saja. Hal ini sesuai dengan penelitian Wulandari, dkk (2021: 209), bahwa siswa kurang memahami materi yang disampaikan guru karena terkadang hanya diberikan materi saja dan tugas tanpa dijelaskan, tidak percaya diri terhadap kemampuannya dalam mengerjakan tugas karena merasa tidak bisa, siswa kurang bisa mengatur waktu untuk mengerjakan tugas dan kegiatan lainya, siswa merasa bosan dan jenuh karena pembelajaran secara daring guru lebih banyak memberikan tugas terus serta kurangnya perhatian dan dorongan motivasi dari orang tua, selain itu dikarenakan pembelajaran dilakukan secara daring.

\section{Hasil Belajar Siswa}

Hasil belajar siswa diambil dari nilai ulangan harian siswa kelas XI dengan nilai rata-rata 89. Hal ini membuktikan bahwa pembelajaran daring berjalan dengan baik. Dengan nilai mencapai KKM atau kriteria ketuntasan minimum yaitu 70 . Nilai berkisar dari nilai 75 sampai dengan nilai 98 . Dimana nilai 75 sebanyak 22 orang siswa dan nilai maksimal atau nilai 98 sebanyak 37 orang siswa. Hasil belajar siswa dapat dilihat pada table 5 . 
Tabel 5 Hasil nilai ulangan harian siswa kelas XI KD 3.14 materi sistem imun

\begin{tabular}{ccc}
\hline Nilai Ulangan Harian & Jumlah Siswa & Keterangan \\
\hline 75 & 22 & Tuntas \\
\hline 80 & 1 & Tuntas \\
\hline 82 & 3 & Tuntas \\
\hline 83 & 3 & Tuntas \\
\hline 84 & 5 & Tuntas \\
\hline 86 & 1 & Tuntas \\
\hline 87 & 6 & Tuntas \\
\hline 89 & 12 & Tuntas \\
\hline 90 & 1 & Tuntas \\
\hline 91 & 15 & Tuntas \\
\hline 95 & 1 & Tuntas \\
\hline 93 & 11 & Tuntas \\
\hline 95 & 5 & Tuntas \\
\hline 96 & 11 & Tuntas \\
\hline 98 & 37 & Tuntas \\
\hline Nilai Rata-rata & & \\
\hline & & 89 \\
\hline
\end{tabular}

Berdasarkan tabel 5 dapat disimpulkan bahwa hasil belajar biologi siswa pada pembelajaran daring KD 3.14 yaitu tentang sistem imun terdapat 22 siswa dengan nilai terendah 75 dan 37 siswa mendapatkan nilai tertinggi yaitu 98. Hasil belajar siswa biologi siswa pada pelajaran biologi selama pembelajaran daring yang dicapai rata-rata diatas kriteria ketuntasan minimal (KKM). Berdasarkan perolehan nilai siswa tersebut sesuai dengan penelitian Utami \& Cahyono (2020: 26), pembelajaran daring dengan menggunakan E-learning dapat membantu siswa dalam menguasai materi sehingga materi yang diharapkan dapat meningkatkan kesadaran bahwa belajar itu penting dan menyenangkan, sehingga memberikan pengaruh yang positif terhadap pelajaran, terjadi peningkatan hasil belajar, sikap dan kinerja siswa juga baik dalam mengikuti pembelajaran sehingga terjadi peningkatan pemahaman siswa pada materi yang sudah dipelajari.

\section{SIMPULAN}

Berdasarkan hasil penelitian dan pembahasan yang telah dilakukan maka dapat disimpulkan bahwa pelaksanaan pembelajaran daring dilaksanakan dengan menggunakan aplikasi E-learning dan whatsapp. E-learning digunakan untuk absen, membagikan materi dan memberikan tugas kepada siswa, sedangkan Whatsapp digunakan untuk memberikan informasi dan komunikasi kepada siswa terkait dengan pelaksanaan pembelajaran daring. Minat belajar siswa terdiri dari empat indikator yaitu perasaaan senang, ketertarikan, perhatian dan keterlibatan. Hasil belajar siswa biologi siswa pada pelajaran biologi selama pembelajaran daring yang dicapai rata-rata diatas ktiteria ketuntasan minimal (KKM) yaitu 70 .

\section{UCAPAN TERIMA KASIH}

Terimakasih kepada Allah SWT yang memberikan kemudahan dan kelancaran pada saat penulisan artikel, kepada Dr. Saleh Hidayat, M.Si dan Dr. Sri Wardhani, M.Si yang telah membimbing. Kepada kepala sekolah serta guru SMA negeri yang menizinkan untuk melakukan penelitian di sekolah tersebut. Ucapan terimakasih juga kepada pihak-pihak yang sudah mendukung dan men-suport untuk menyelesaikan penelitian ini. 


\section{RUJUKAN}

Anugrahana, A. (2020). Hambatan, Solusi dan Harapan: Pembelajaran Daring Selama Masa Pandemi Covid-19 Oleh Guru Sekolah Dasar. Jurnal Pendidikan dan Kebudayan, 10 (3): 282-289.

Dalimunthe, R. R., Harahap, R. D., \& Harahap, D. A. (2021). Analisis Minat Belajar Siswa Sekolah Dasar terhadap Mata Pelajaran IPA pada Masa Pandemi Covid-19. Jurnal Basicedu, 5 (3): 1341-1348.

Dewi, W. A. (2020). Dampak Covid-19 terhadap Implementasi Pembelajaran Daring di Sekolah Dasar. Jurnal IImu Pendidikan, 2 (1): 55-61.

Maulidar, Hambali, \& Aklima, F. N. (2019). Hubungan Intensitas Bermain Game Online dengan Prestasi Belajar Siswa di SD Negeri 2 Banda Aceh. Jurnal Tunas Bangsa, 6 (2): 302-310.

Nasution, F. H., Hasibuan, I. S., \& Lubis, J. A. (2017). Peningkatan Hasil Belajar Biologi Siswa Melalui Penerapan Model Pembelajaran Kooperatif Tipe Group Investigation (GI). Jurnal Peneltian Tindakan Kelas dan Pengembangan Pembelajaran, 1 (1): 28-33.

Nurhabibah, P., Hanikah, \& Widiawati, H. (2020). Aplikasi Pilihan Pendukung Pembelajaran Daring pada Mahasiswa Pendidikan Guru Sekolah Dasar. Jurnal Riset Pedagogik. 2 (2): 257-264.

Nurkholis. (2013). Pendidikan dalam Upaya Memajukan Teknologi. Jurnal Kependidikan, 1 (1): 24-44.

Sirait, E. D. (2016). Pengaruh Minat Belajar terhadap Prestasi Belajar Matematika. Jurnal Formatif, 6 (1): 35-43.

Syarifudin, A. S. (2020). Implementasi Pembelajaran Daring untuk Meningkatkan Mutu Pendidikan sebagai Dampak Diterapkannya Social Distancing. Jurnal Pendidikan Bahasa dan Sastra Indonesia, 5 (1): 31-34.

Utami, Y. P., \& Cahyono, D. A. (2020). Study At Home: Analisis Kesulitan Belajar Matematika pada Proses Pembelajaran Daring. Jurnal IImiah Matematika Realistik, Vol 1 No (1) HIm 20-26.

Viviantini, Rede, A., \& Saehana, S. (2015). Pengaruh Media Video Pembelajaran terhadap Minat dan Hasil Belajar IPA Siswa Kelas VI SDN 6 Kayumalue Ngapa. Jurnal Sains dan Teknologi Taduloko, 4 (1): 66-71.

Wulandari, I., Fatimah, S., \& Suherman, M. M. (2021). Gambaran Faktor Penyebab Prokrastinasi Akademik Siswa SMA Kelas XI pada Masa Pandemi Covid-19. FOKUS, 4(3): 200-211. 